\title{
Strategic Environmental Assessment of Towns in Ecuador with Tourism Potential
}

\author{
Lourdes Ruiz \\ International University of Ecuador, Quito, Ecuador \\ Email:Iruiz@internacional.edu.ec
}

Received 19 February 2016; accepted 19 March 2016; published 22 March 2016

Copyright @ 2016 by author and Scientific Research Publishing Inc.

This work is licensed under the Creative Commons Attribution International License (CC BY). http://creativecommons.org/licenses/by/4.0/

(c) (i) Open Access

\begin{abstract}
The aim of this study is to apply the methodology for assessment of environmental impact whether of a physicochemical nature and on the biodiversity and ecosystems, or whether sociocultural and economic aspects of the historic towns with tourism interest that are assessed. The automated method of the RIAM software is used which requires a baseline study of the environment of different towns to be prepared. In addition, the analysis of the social perception on tourism of the local people from the course work of students at the UIDE shall be applied. The conclusions of the case studies undertaken allow for strategic proposals and recommendations to be prepared so that they can be incorporated into the management plans for tourism in the historic towns with heritage value.
\end{abstract}

\section{Keywords}

\section{Environmental Impact, Towns}

\section{Introduction}

The historic towns of heritage interest are currently a subject of high interest. Tourism is an economic vehicle for historic towns, providing it is undertaken with a focus on sustainability, based on respect for the indigenous culture, the environment and tangible and intangible cultural heritage. Sustainability implies a rational relationship between man and nature; changes which affect the natural environment impose limits which should be analyzed prior to creating disturbances therein [1].

The application of methods of environmental analysis in the field of urban heritage for tourism allows the study and assessment of the actions created by the planning activity, with a view to determining, predicting, interpreting and communicating the negative impacts that these actions cause in the environment under current conditions, in order to reach a social model with approaches to sustainability in tourism. In this context, the local 
environmental impact of the towns involved in tourism could cause undesirable effects on the target environment within a particular area, and the aforementioned can also be called potential impacts, which ultimately are the most severe and fall under the scope of the study. The characteristics of the environmental impacts appear expressed in different environmental impact assessment methodologies with different attributes, such as: nature, connotation, magnitude, significance, synergy, scope and reversibility [2] [3].

The term "environmental impact" is cited in many classics in world literature and indicates the change that the implementation of a Project inflicts on the environment, expressed between the evolution of this "with" and "without" Project. According others authors [4], its environmental significance, interpreted in terms of human health and well-being, is what defines the environmental impact. Some authors [4] [5], argue that the environmental impact is the direct and indirect consequence, beneficial (positive) or adverse (negative), which is produced by man in the natural and socioeconomic systems, upon which man's well-being depends, as a result of environmental change, caused by an action or a set of actions which are human or natural in origin. The public works such as the construction of a highway, a city, an industry and a recreational are or any activity of these, have an impact on the environment [6].

The environmental impact assessment (EIA) in the international arena, is a tool for planning investment and decision making which in the nineties achieved improvement in its implementation, scope and as a creative activity for participative environmental management with regards to plans, programs, policies and strategies for sustainable development.

A systematic process of the EIA and the implementation of environmental management strategies incorporate the approaches for sustainable development in the conception of the investment projects, bearing the future in mind. The purposes of the EIA as a tool for environmental management for sustainable development essentially consist of the scientific information offered for designing strategies to protect the environment.

The assessment of projects, which prior to the sixties mainly analyzed functionality, incorporated the financial economic assessment in parallel with the recognition of the social function of the projects. The seventies saw the addition of the environmental analysis which evolved in the eighties together with the concept of total quality and comparative profitability in integrated project management. The environmental impact assessment is inserted into this new context, with an important role in its contribution as a tool for sustainable development, which includes the prediction of environmental impacts and the analysis of environmental economics, quality of life and public participation; in addition to the traditional criteria with regards to the exact nature of the project and its location.

\section{Research Methodology}

Environmental assessments are often performed by way of the use of matrix methods in which one dimension of the matrix is "impact factors" (F) and the other is the "environmental components" (EC), which are affected by the impacting factors [7].

Due to the need to undertake environmental assessments, various methods can be used wherein a new method for the assessment of environmental impact stands out: the Rapid Impact Assessment Matrix (RIAM). This semi-quantitative method seeks to overcome the problems of subjective judgement through the definition of criteria and scales by way of which the outcomes in a correlation matrix allow for a permanent record of the criteria from experts in the study [8].

The methodology for the environmental impact assessment, whether of a physicochemical nature and on the biodiversity and ecosystems, or whether sociocultural and economic aspects of the 8 towns with tourism interest that are assessed is applied. The automated method of the RIAM software is used which requires a baseline study of the environment of different towns to be prepared.

The mathematical criteria for assessment by the RIAM method [8] should be defined for the independent and dependent variables, which are based on the intervening variables that may be conditioned by the change in the location of the individual projects.

The valuation of the environmental impacts comprises assigning a concrete (objective measurement) or abstract (subjective measurement) value to the environmental impacts as a basis for establishing evaluative, quantitative or qualitative judgments. It is based on the identification of variables and indicators, the measuring and establishing value judgments. The values obtained can generally be expressed in terms of relevance, priority or magnitude [9]. 
It is theoretically possible to define a set of criteria, but two principles must always be met, that is: the universality of the criteria, in order to allow it to be used in different EIA and the value of the criteria, which determines whether it should be treated as an independent variable of group (A) or a dependent variable of group (B), [8].

The defined environmental variables are used depending on the set of roles that they play in the environment by intervening in ordinary production and profits as well as the support to all life and activity. They can be independent, dependent or involved for the purposes of this study.

The positive and negative impacts can be assessed by way of the use of scales ranging from negative values to positive ones through zero for the independent variables of group (A). The values nearest zero indicate "nochange" or "insignificant change". The dependent variables in group (B) are not assigned magnitudes with positive or negative values [8].

At the same time it is necessary to use the method for analysis and synthesis to study the fundamental contributions to the object of the assessment and to verify its validity in the field of tourism constructions. This method is also present when it is taken into account that the object of the investigation is located in an economic, political, social and biogeographical context different to those addressed in the repertoire of other national and international works. The method used, allows human contradictions to be confronted, which drive the need for accelerated economic development in adverse conditions for survival and economic blockade for improvements in the quality of life of the society exploiting its natural resources (cause). It also considers the alternative that this exploitation leads to degradation of the environment and to the irrecoverable loss of its biodiversity (effect), the receiver of which is man himself and his descendants.

The RIAM methodology for environmental impact assessment [8] has been applied to different case studies of historic towns with tourism interest in Ecuador by various exercises and course work of students on the tourism course at our university, UIDE, in the headquarters in Quito and by a graduation thesis completed by an tourism student from the International University of Ecuador (UIDE). I Information from statistics was processed [8].

\section{Development}

Different case studies were undertaken for a sample of the following six towns in Ecuador:

- Three towns in the city of Quito, Ecuador: Guápulo, Amaguaña, and Nayon.

- Two towns in the province of Loja, Ecuador: Vilcabamba and Catamayo.

- A town in city of Tungurahua, Ecuador: Baños de Aguas Santas.

For each of the six towns assessed different results were obtained in some variables and similar results in others. The outcomes of the aforementioned analysis is expressed in the four environmental components or environmental dimensions of sustainability in accordance with the guide for analysis of the physical and socio-economic environment described in a simplified guide for baseline studies (Table 1) and are grouped into the following components: physicochemical, physicochemical],biological-ecological, sociocultural and economic-operational.

The criteria used in this study to determine the impacts that occur under a strategy for development of tourism in a town or under a planning program and projection of tourism infrastructure in heritage sites should take the following into account: the area that may be affected by the intervention of tourism.

Also assessed was the degree or magnitude of the impact whether it be negative or adverse, positive or beneficial and whether the change that would arise due to tourism would be permanent or temporary. It was necessary to acknowledge whether the adverse effect could be reversed, whether the impact could be increased with the synergy of other negative effects and whether there was any likelihood of the accumulative effect being very severe and difficult to manage in the medium and long term period of time. The components to be assessed [8] are:

- Physical-chemical component: address all the physical and chemical aspects of the natural resources in the abiotic environment (air, surface and groundwater and soils) and the degradation of the physical environment by pollution to the environmental matrices, and including solid waste and dangerous residues.

- Biological-ecological component: includes all the biological aspects of the environment, flora, vegetation, fauna, conservation of biodiversity, the ecosystems and the interactions between the species and the contamination of the biosphere and natural heritage. 
Table 1. Simplified guide for environmental baseline studies.

\begin{tabular}{|c|c|c|}
\hline Environment component & Aspects & Description of the aspects to be assessed \\
\hline \multirow{7}{*}{ Physicochemical } & $\begin{array}{l}\text { Geology and } \\
\text { Geomorphology }\end{array}$ & $\begin{array}{c}\text { Types of rocks. Geotechnic characteristics and mineral deposits. } \\
\text { Relief, slope analysis. }\end{array}$ \\
\hline & Soils & Characteristics of soils. Potential for exploitation. \\
\hline & Seismic conditions & $\begin{array}{l}\text { Seismotectonic characterization seismic danger of area. } \\
\text { Construction alternatives for the Project. }\end{array}$ \\
\hline & Air quality & $\begin{array}{l}\text { Possible emissions from the Project. Areas of health protection. Level of } \\
\text { continuous and isolated noise. Particulate emissions and greenhouse gases. }\end{array}$ \\
\hline & Climate & $\begin{array}{l}\text { Microclimate, air quality and influence of the Project. } \\
\text { Temperature, winds, humidity, precipitation, insulation, evapotranspiration. }\end{array}$ \\
\hline & Fresh water & $\begin{array}{l}\text { Availability, management and quality of public service. } \\
\text { Sources of supply. Surface water, groundwater and quality thereof. } \\
\text { Natural and artificial drainage systems. Sources of pollution. }\end{array}$ \\
\hline & Salt water & Quality of coastal and marine waters. Currents, tides and sources of pollution. \\
\hline \multirow{3}{*}{$\begin{array}{l}\text { Biological- } \\
\text { ecological }\end{array}$} & Vegetation and flora & $\begin{array}{l}\text { Types and formations of terrestrial, aquatic and marine vegetation. } \\
\text { Endemic species or those in danger of extinction, } \\
\text { fragile or highly vulnerable ecosystems. Forests. Urban green areas. }\end{array}$ \\
\hline & Fauna & $\begin{array}{l}\text { Status and distribution of terrestrial, aquatic and marine fauna. } \\
\text { Endemic species or those in danger of extinction. } \\
\text { Habitat, ecosystems and migrations. Fisheries and wildlife. }\end{array}$ \\
\hline & Ecological Relationships & $\begin{array}{l}\text { Protected areas, management and areas of high environmental sensitivity. } \\
\text { Relationships: climate-vegetation-soil; climate-relief-vegetation. }\end{array}$ \\
\hline \multirow{2}{*}{$\begin{array}{l}\text { Sociocultural } \\
\text { environment }\end{array}$} & $\begin{array}{l}\text { Village settlements and } \\
\text { social stakeholders }\end{array}$ & $\begin{array}{l}\text { Key village settlements and social stakeholders. } \\
\text { Social behavior and poverty. Total population, resident and eventual, } \\
\text { by age and sex. Work force. Education and health. }\end{array}$ \\
\hline & $\begin{array}{l}\text { Cultural heritage and } \\
\text { recreation }\end{array}$ & $\begin{array}{l}\text { Historical and cultural traditions. Tangible and intangible heritage of historical and } \\
\text { architectural value, monuments, and works of architectural value. Recreation. }\end{array}$ \\
\hline \multirow{2}{*}{$\begin{array}{l}\text { Economic-operational } \\
\text { environment }\end{array}$} & Economic relationships & Type of property by sector, Income and average salary. \\
\hline & Services & Basic services available to the community and their quality. Infrastructure. \\
\hline
\end{tabular}

- Socio-cultural component: includes all human aspects of the environment, the social questions that affect the individuals and the communities, together with the cultural aspects, including the conservation of the tangible and intangible cultural heritage, health, education, ways of life and customs, human identity and development.

- Economic-operational component: enables qualitative identification of the economic consequences of the environmental changes in this case the impact of tourism on the historic towns and the temporary or permanent changes to the local economy and infrastructures, the sources of employment and the income of residents, in accordance with the complexity of the management of projects in the context of the project activities.

The aforementioned groups of variables have the following characteristics [8].

- (-A): Independent variables with the criteria that they are important for the condition, and can individually change the score obtained. Where $(-\mathrm{A} 1) \cdot(-\mathrm{A} 2)$ is -AT which is the result of the multiplication of all the (-A) scores.

- (-B): Dependent variables with the criteria that they are of value to the situation but individually they are not able to change the score obtained. Where $(-\mathrm{B} 1)+(-\mathrm{B} 2)+(-\mathrm{B} 3)$ is BT which is the result of the sum of all the (-B) scores.

- (ES): which comprise the final outcome of the assessment and is the product of (-AT) by (-BT).

The full EIA report will detail the criteria used, the components derived, the RIAM matrix, and the Information from statistics was processed. The range used for RIAM is given (Table 2).

The physical, biological, socio-cultural and economic environment of the site chosen for the case study was examined and was complemented with the RIAM method [8], compared to similar small towns ecosystems [9]. The result is given (Table 3 ). 
Table 2. Range value used for RIAM [8] in six towns in Ecuador for environmental negative impacts.

\begin{tabular}{|c|c|c|}
\hline Environmental negative impacts. & Range statistics value & Resulting values (ES) \\
\hline No change/not applicable & 0 & 0 \\
\hline Slight negative change/impact & -1 to -9 & $-\mathrm{AT}$ \\
\hline Negative change/impact & -10 to -18 & -BT \\
\hline Moderate negative change/impact & -19 to -35 & $-\mathrm{CT}$ \\
\hline Significant negative change/impact & -36 to -71 & -DT \\
\hline Major negative change/impact & -72 to -108 & $-\mathrm{ET}$ \\
\hline
\end{tabular}

Table 3. Result of RIAM method compared to similar small towns ecosystems.

\begin{tabular}{|c|c|c|c|c|}
\hline \multirow{2}{*}{ Towns } & \multicolumn{4}{|c|}{ Environment component } \\
\hline & $\begin{array}{l}\text { Physical chemical } \\
\text { component }\end{array}$ & $\begin{array}{l}\text { Biological ecological } \\
\text { component }\end{array}$ & $\begin{array}{c}\text { Socio-cultural } \\
\text { component }\end{array}$ & $\begin{array}{l}\text { Economic operational } \\
\text { component: }\end{array}$ \\
\hline Guápulo & $-\mathrm{CT}$ & -BT & $-\mathrm{CT}$ & 0 \\
\hline Amaguaña & $-\mathrm{CT}$ & -BT & -AT & 0 \\
\hline Nayón & $-\mathrm{CT}$ & $-\mathrm{BT}$ & -AT & 0 \\
\hline Vilcabamba & $-\mathrm{CT}$ & -BT & -DT & 0 \\
\hline Catamayo & -CT & -BT & -AT & 0 \\
\hline Baños de Aguas Santas & $-\mathrm{CT}$ & -BT & $-\mathrm{AT}$ & 0 \\
\hline
\end{tabular}

\section{Results and Discussion}

The outcomes from the sample of six towns in Ecuador (Guápulo, Amaguaña, and Nayón in Quito; Vilcabamba and Catamayo in Loja and Baños de Aguas Santas in Tungurahua) display some similarities in the physicalchemical components of the adverse impacts occurring, particularly in the deterioration of the quality of water, soil and air (vehicular and noise pollution).

In addition the biological and ecological aspects display that in all of them negative effects have occurred from deforestation, changes to habitats and through the introduction of exotic species of vegetation.

The adverse effects of the socio-cultural component result in differences in each town. However, the situation is not reported unfavorably in Baños de Aguas Santas, according to interviews with local residents [10].

Environmental impacts through human actions in the town of Guápulo, located in Quito can be seen with minor negative affectations resulting in the economic and socio-cultural components, however, there is evidence that the environmental factors may affect the architectural cultural heritage due to the issues of air and noise pollution as a result of excessive vehicular traffic and inconvenience caused to residents. There is also evidence of river pollution and effects on biodiversity, the natural ecosystems and the landscape [11].

The most critical situation of the socio-cultural component can be seen in Vilcabamba, in the Loja province, due to the inadequate management of land ownership and the introduction of new foreign customs by foreign residents, even though there are also positive impacts in the form of a way of life linked to the ecology and the cultivation of organic food [12].

The economic impacts of tourism are reported as positives, due to the increase in sources of employment and the improvement of the urban infrastructure in the six towns assessed.

There is no analysis of alternatives in the towns where tourism projects have been introduced without being assessed. There is a tendency towards subjective and arguable balancing of the benefits of tourism in the studies undertaken, given that the studies are carried our as a static and non-spatial analysis of the environmental impacts.

There is insufficient awareness among the residents of the accumulative impacts from tourism and the synergy effects from each type of tourism developed in relation to the characteristics and the identity of the historic 
towns.

The proposed measures and monitoring [13] are generally weak in the tourism companies and on occasions, and there are environmental impact studies. There is poor implementation of environmental monitoring and auditing by municipalities and other public institutions.

\section{Conclusions}

The RIAM method is appropriate because it favors an investigation being undertaken by a team of multidisciplinary investigators, given that the data from different towns are assessed and can be analyzed thus providing a clear evaluation of the main impacts.

The application of the RIAM methodology to the historic towns with tourism potential allowed the assessment of the environmental impacts of a physicochemical nature and on the biodiversity and ecosystems. It was a useful tool for evaluating the socio-cultural and economic-operational effects that occurred and that were predicted as a product of the development of tourism in the selected case studies in different settings, projects and specific environmental situations in different planning options.

The conclusions of the case studies undertaken enable the preparation of strategic proposals and recommendations that could be incorporated into the tourism management plans in the historic towns with heritage value.

The legal, economic and regulatory tools are not effective on their own in order to create awareness and attitude about the need for the protection and care of the environment, if they are not accompanied by a strong environmental culture that preserves nature and the cultural identity of the towns.

Education and environmental disclosure need to be reinforced encompassing all the bodies, institutions and the community. It is imperative to develop programs for improvement and training of those who make decisions, technicians and workers in general.

\section{References}

[1] Ruiz, L. and García, D (2014) Análisis de la falla ambiental de las construcciones turísticas en ecosistemas costeros. Cub@: Medio Ambiente y Desarrollo; Revista electrónica de la Agencia de Medio Ambiente. Año 14, No. 26. https://www.academia.edu/10509722/

[2] Gutiérrez, L. (2015) Impact Assessment of Tourism Construction in Cuba. Journal of Building Construction and Planning Research, 3, 10-17. http://dx.doi.org/10.4236/jbcpr.2015.31002

[3] Gutiérrez, L. (2015) The Environmental Effects of Tourism Architecture on Island Ecosystem in Cayo Guillermo, Cuba. Journal of Environmental Protection, 6, 1057-1065. http://dx.doi.org/10.4236/jep.2015.69093

[4] Gómez, D. and Gómez, T. (2013) Evaluación de Impacto Ambiental. 3ra. Edición, S.A. Mundi-Prensa Libros, Madrid, $748 \mathrm{p}$.

[5] Garmendia, A., et al. (2014) Evaluación de Impacto Ambiental. E-Book. Editorial: Pearson. http://ebooksacademicos.blogspot.com/2014/02/evaluacion-de-impacto-ambiental-alfonso.html

[6] Gutiérrez, L.R. (1999) La evaluación de impacto ambiental de las construcciones turísticas en la Cayeria Norte y otras zonas costeras de Cuba. Tesis para la obtención del grado científico de Doctora en Ciencias Técnicas. ISPJAE, La Habana.

https://www.academia.edu/10509977/La_evaluacion_de_impacto_ambiental_de_las_construcciones_turisticas_en_la Cayeria_Norte_y_otras_zonas_costeras_de_Cuba

[7] Namin, F., et al. (2014) New Model for Environmental Impact Assessment of Tunneling Projects. Journal of Environmental Protection, 5, 530-550. http://dx.doi.org/10.4236/jep.2014.56056

[8] Pastakia, C. (1998) The Rapid Impact Assessment Matrix (RIAM)—A New Tool for Environmental Impact Assessment. VKI, Agern Alle 11, DK-2970 Hørsholm.

[9] Ruiz, L. (2015) The Effects of Tourism Architecture on Island Ecosystems. Journal of Building Construction and Planning Research, 3, 163-170. http://dx.doi.org/10.4236/jbcpr.2015.34016

[10] Velasco, G., et al. (2015) Estudio ambiental de Baños de Aguas Santas. Trabajo de curso. UIDE, Quito. Inédito.

[11] Zúñiga, M. and Palomeque, J. (2015) Estudio ambiental de Guápulo. Trabajo de curso. UIDE, Quito. Inédito.

[12] Riofrio, E. (2015) Regeneración sostenible de la plaza central de la parroquia Vilcabamba de la provincia de Loja. Trabajo de Observación para tesis. UIDE, Loja. Inédito.

[13] O’Reilly, V., Bancrofft, R. and Ruiz, L. (2010) Las tecnologías del concreto en su ciclo de vida. México. Concreto y Cemento: Investigación y Desarrollo. Revista CONPAT, 1, $42-47$. 